\title{
Clinic and therapeutic potential of non-coding RNAs in cancer
}

Since the early beginning of the 21th century, the research in molecular and translational oncology has been going deeper and deeper in the exploration of the non-coding human transcriptome (1,2). A simple comparison of the number of publications in PubMed containing the "non-coding RNA" and "cancer" words between the years 2000 and 2019 reveals an increase fold of 29.8 in the number of matches. This data highlights the weight and interest that non-coding RNAs (ncRNAs) has reached in the last years.

The ncRNAs comprises a vast family of different RNA molecules, mainly divided according to its size in small non-coding RNAs (sncRNAs) and long non-coding RNAs (lncRNAs) (3). Both families, has been related to all hallmarks of cancer $(4,5)$. Within the sncRNA, microRNAs have been extensively studied and are well known players in tumorigenesis, acting as both oncogenes and tumor suppressors (6,7). MicroRNAs are key players in gene expression regulation, mainly at post-transcriptional level avoiding the translation of their target mRNAs (8). Several microRNAs identified across different cancer types acts as oncogenes by targeting the expression of different tumor suppressor genes such as RB1 or TGFBR2 (9). Other sncRNAs types such as piwiRNAs has identified as regulators of the genomic stability in germ line (10). However, their role in cancer initiation remains poorly understood, and further characterization is needed (11).

LncRNAs plays a plethora of roles in cancer progression related to different key events for tumorigenesis such as epithelial-to-mesenchymal transition (12), angiogenesis (13) or tumor metabolism (14). They can act according to four different functional archetypes as: signals, relating its differential expression to a concrete cellular process or context; scaffolds, allowing different protein component of a complex to spatially join; decoys, disrupting the interaction between two different cellular components; or guides, recruiting transcription factors or protein complexes to the genomic locations where they act (15). Additionally, they has been proposed as an ideal source of biomarkers, due to its highly specific expression pattern across different cancer types and between normal and tumor tissue (16). LncRNAs includes different members such as long intergenic non-coding RNAs (lincRNAs) or antisense lncRNAS (AS-lncRNAs) well characterized in the last years (17), and other members that begin to be explored such as circular RNAs (circRNAs) (18).

The potential of ncRNAS has been studied from the basis of the molecular oncology, dissecting its biological function, to the translational research, demonstrating its high applicability as biomarkers (19). Furthermore, their potential use as biomarkers in clinics is enhanced by the field of liquid biopsy. It has been proved that, the detection of ncRNAs in different biofluids, as freecirculating RNAs or as part of extracellular vesicles cargo, is an ideal source of diagnostic, prognostic and response-monitoring biomarkers (20).

In summary, even though the efforts made to date in the exploration of ncRNA's role in cancer, there is still further research needed about their utility not only as biomarkers, but also as therapeutic targets. The present special series will explore todays knowledge about the potential role of ncRNAs in the clinic, especially in the liquid biopsy field, and intends to shed light into the future questions to be raised on this matter.

\section{Acknowledgments}

Funding: This work was supported by grants from the Ministry of Economy, Industry, and Competition, Agencia Estatal de Investigación co-financed with the European Union FEDER funds SAF2017-88606-P (AEI/FEDER, UE) and from Instituto de Salud Carlos III funds FIS PI16/01027 and FIS PI19/01476.

\section{Footnote}

Provenance and Peer Review: This article was commissioned by the editorial office, Translational Cancer Research for the series "Clinic and Therapeutic Potential of Non-coding RNAs in Cancer". The article did not undergo external peer review.

Conflicts of Interest: All authors have completed the ICMJE uniform disclosure forms (available at https://dx.doi.org/10.21037/ 
tcr-2020-ctp-01). The series "Clinic and Therapeutic Potential of Non-coding RNAs in Cancer" was commissioned by the editorial office without any funding or sponsorship. Drs. Castellano, Díaz-Beyá and Navarro served as the unpaid Guest Editors of the series. Dr. Navarro serves as an unpaid editorial board member of Translational Cancer Research from Sep 2019 to Aug 2021. The authors have no other conflicts of interest to declare.

Ethical Statement: The authors are accountable for all aspects of the work in ensuring that questions related to the accuracy or integrity of any part of the work are appropriately investigated and resolved.

Open Access Statement: This is an Open Access article distributed in accordance with the Creative Commons AttributionNonCommercial-NoDerivs 4.0 International License (CC BY-NC-ND 4.0), which permits the non-commercial replication and distribution of the article with the strict proviso that no changes or edits are made and the original work is properly cited (including links to both the formal publication through the relevant DOI and the license). See: https://creativecommons.org/licenses/by-nc$\mathrm{nd} / 4.0 /$.

\section{References}

1. Anastasiadou E, Jacob LS, Slack FJ. Non-coding RNA networks in cancer. Nat Rev Cancer 2018;18:5-18.

2. Ling H, Girnita L, Buda O, et al. Non-coding RNAs: the cancer genome dark matter that matters! Clin Chem Lab Med 2017;55:705-14.

3. Carninci P, Kasukawa T, Katayama S, et al. The transcriptional landscape of the mammalian genome. Science 2005;309:1559-63.

4. Van Roosbroeck K, Calin GA. Cancer Hallmarks and MicroRNAs: The Therapeutic Connection. Adv Cancer Res 2017;135:119-49.

5. Gutschner T, Diederichs S. The hallmarks of cancer: a long non-coding RNA point of view. RNA Biol 2012;9:703-19.

6. Esquela-Kerscher A, Slack FJ. Oncomirs-microRNAs with a role in cancer. Nat Rev Cancer 2006;6:259-69.

7. Hammond SM. MicroRNAs as tumor suppressors. Nat Genet 2007;39:582-3.

8. Bushati N, Cohen SM. microRNA functions. Annu Rev Cell Dev Biol 2007;23:175-205.

9. Volinia S, Calin GA, Liu CG, et al. A microRNA expression signature of human solid tumors defines cancer gene targets. Proc Natl Acad Sci U S A 2006;103:2257-61.

10. Klattenhoff C, Theurkauf W. Biogenesis and germline functions of piRNAs. Development 2008;135:3-9.

11. Cheng J, Guo JM, Xiao BX, et al. piRNA, the new non-coding RNA, is aberrantly expressed in human cancer cells. Clin Chim Acta 2011;412:1621-5.

12. Samatov TR, Tonevitsky AG, Schumacher U. Epithelial-mesenchymal transition: focus on metastatic cascade, alternative splicing, non-coding RNAs and modulating compounds. Mol Cancer 2013;12:107.

13. Sheng SR, Wu JS, Tang YL, et al. Long noncoding RNAs: emerging regulators of tumor angiogenesis. Future Oncol 2017;13:1551-62.

14. Sun H, Huang Z, Sheng W, et al. Emerging roles of long non-coding RNAs in tumor metabolism. J Hematol Oncol 2018;11:106.

15. Huang Y, Liu N, Wang JP, et al. Regulatory long non-coding RNA and its functions. J Physiol Biochem 2012;68:611-8.

16. Yan X, Hu Z, Feng Y, et al. Comprehensive genomic characterization of long non-coding RNAs across human cancers. Cancer Cell 2015;28:529-40.

17. St Laurent G, Wahlestedt C, Kapranov P. The Landscape of long noncoding RNA classification. Trends Genet 2015;31:239-51.

18. Meng S, Zhou H, Feng Z, et al. CircRNA: functions and properties of a novel potential biomarker for cancer. Mol Cancer 2017;16:94.

19. Bolha L, Ravnik-Glavač M, Glavač D. Long Noncoding RNAs as Biomarkers in Cancer. Dis Markers 2017;2017:7243968.

20. Dragomir M, Chen B, Calin GA. Exosomal lncRNAs as new players in cell-to-cell communication. Transl Cancer Res 2018;7:S243-52. 


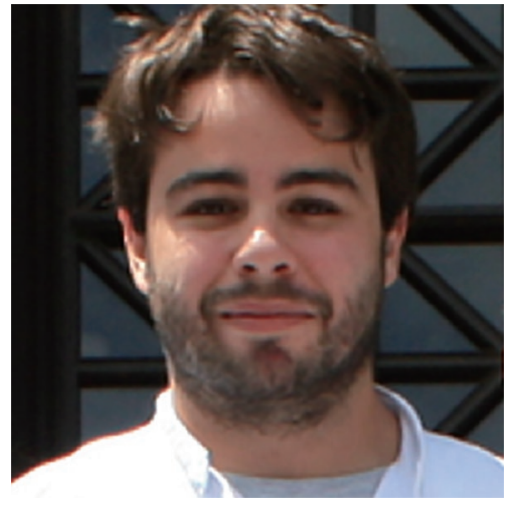

Joan Josep Castellano

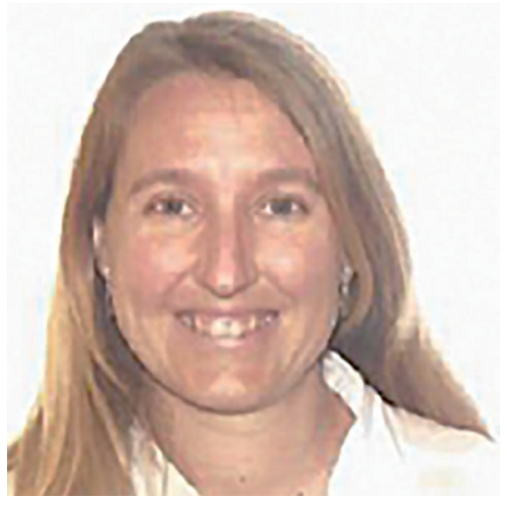

Marina Díaz-Beyá

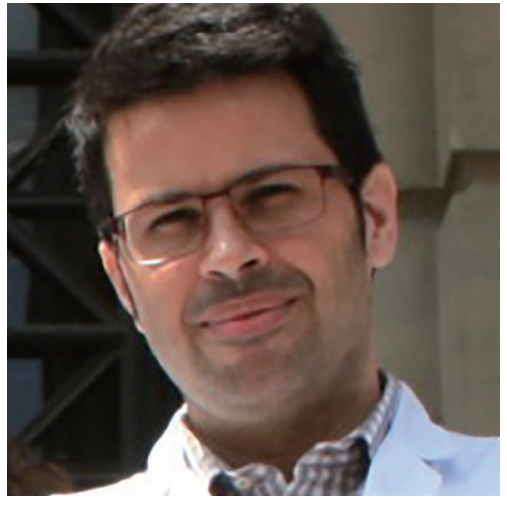

Alfons Navarro

Joan Josep Castellano, PhD Human Anatomy Unit, Faculty of Medicine and Health Sciences, University of Barcelona, Barcelona, Spain.

(Email: joan.castellano@ub.edu)

Marina Díaz-Beyá, $\mathrm{MD}, \mathbf{P h D}$

Hematology department, Hospital Clinic of Barcelona, Barcelona, Spain.

(Email: diazbeya@clinic.cat)

Alfons Navarro, PhD

Human Anatomy and Embryology Unit, Faculty of Medicine and Health Sciences, University of Barcelona, Barcelona, Spain.

(Email: anavarroponz@ub.edu)

Submitted Apr 20, 2020. Accepted for publication Dec 10, 2020.

doi: $10.21037 /$ tcr-2020-ctp-01

View this article at: https://dx.doi.org/10.21037/tcr-2020-ctp-01

Cite this article as: Castellano JJ, Díaz-Beyá M, Navarro A. Clinic and therapeutic potential of non-coding RNAs in cancer. Transl Cancer Res 2021;10(6):3087-3089. doi: 10.21037/tcr-2020-ctp-01 